dr MAŁGORZATA PĘCIŁŁO (ORCID: 0000-0003-2148-8781)

Centralny Instytut Ochrony Pracy - Państwowy Instytut Badawczy

\title{
Ocena procesów zarządzania bhp - aspekty teoretyczne
}

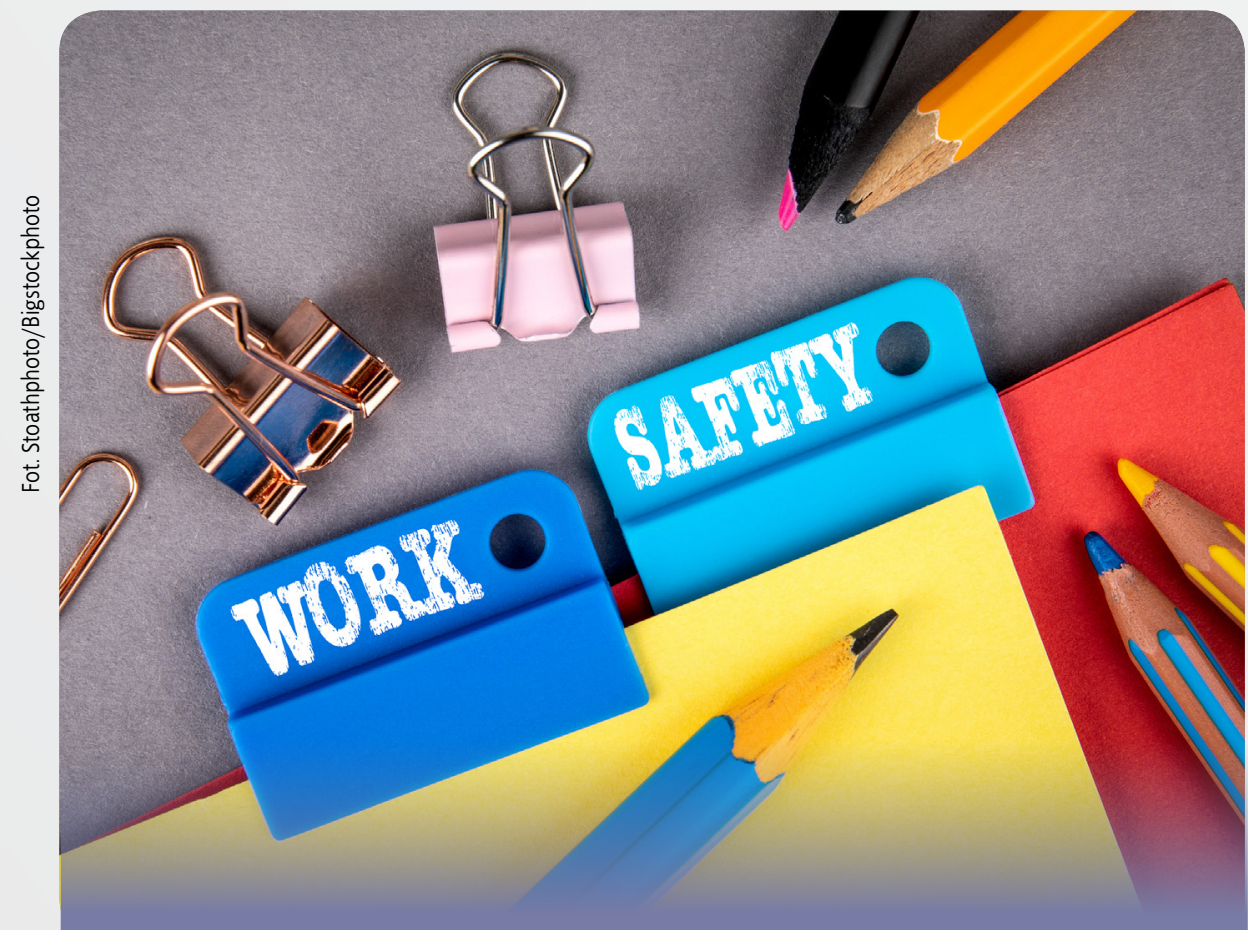

Ocena skuteczności i efektywności procesów zarządzania bezpieczeństwem i higieną pracy stanowi aktualny problem, zwłaszcza w dynamicznie zmieniającym się otoczeniu organizacji - bliższym i dalszym. Brak reżimu terminologicznego utrudnia zrozumienie różnych podejść do oceny tych procesów. W artykule dokonano próby uporządkowania terminologii w tym zakresie oraz przedstawiono dwa odmienne narzędzia do oceny procesów zarządzania bhp, które można z powodzeniem wykorzystać w praktyce, w zależności od celu i potrzeb przedsiębiorstwa.

Słowa kluczowe: procesy zarządzania bhp, wskaźniki wiodące, wskaźniki wynikowe, skuteczność, efektywność

\section{Measurement of OSH management processes - theoretical aspects}

Measuring the effectiveness and efficiency of occupational health and safety management processes is a current problem, especially in the dynamically changing environment of the organization - both immediate and further. The lack of a terminological regime makes it difficult to understand the different approaches to measuring these processes. The article attempts to organize the terminology in this area and presents two different tools for assessing OSH management processes, which can be successfully used in practice, depending on the purpose and needs of the enterprise.

Keywords: OSH management processes, leading indicators, result indicators, effectiveness, efficiency

\section{Wstęp}

Wśród przedstawicieli przedsiębiorców oraz osób zajmujących się zarządzaniem jako nauką od lat popularny jest pogląd, wyrażony przez Druckera, austriackiego eksperta ds. zarządzania, że jeżeli nie można czegoś zmierzyć, nie można tym zarządzać [1, 2]. Mierniki pełnią bo wiem w zarządzaniu zasadniczo trzy funkcje [3]:

- umożliwiają ocenę osiągniętych wyników i zasadności wykorzystanych zasobów

- są nieodłącznym elementem komunikacji - za pomocą mierników można w klarowny i syntetyczny sposób przekazać szerokiemu spektrum interesariuszy (od pracowników przez klientów, dostawców i podwykonawców, do organów nadzoru czy społeczeństwa jako całości) najważniejsze informacje o działaniach realizowanych w różnych obszarach funkcjonalnych

- stanowią punkt wyjścia do podjęcia działań korygujących lub zapobiegawczych albo mogą być wskazówką (w przypadku osiągnięcia pozytywnych wyników), że procesy zarządzania w organizacji są realizowane we właściwy sposób.

Dobrze skonstruowany system oceny działań organizacji jest narzędziem, które pomaga przełożyć jej strategię na konkretne działania. Tymczasem badacze zauważyli, że w wielu przypadkach związek pomiędzy podejmowanymi działaniami a strategią jest słaby. Miary niefinansowe - takie jak: satysfakcja klienta, jakość, motywacja oraz lojalność pracowników i klientów - często stosuje się jako zbiór luźno powiązanych wskaźników, bez odnoszenia ich do realizacji strategii przedsiębiorstwa [3-5]. Podobnie jest w obszarze bezpieczeństwa i higieny pracy. Petersen zwrócił uwagę, że być może największym problemem związanym z bezpieczeństwem był - i nadal jest - pomiar [6]. Doświadczenia we współpracy z przedsiębiorstwami pokazu ją, że ten problem wciąż jest aktualny. Jedna z przyczyn tej sytuacji tkwi w braku zrozumienia, czemu mają służyć pomiar i ocena procesów zarządzania bhp, a konsekwencją tego jest problem z wyznaczeniem adekwatnych wskaźników i ich późniejszym zastosowaniem. Ponadto brak reżimu terminologicznego utrudnia komunikację w tym zakresie - zarówno wewnątrz organizacji, 
jak i pomiędzy organizacjami. Melnyk i inni [3] zwracają uwagę na dwie zasadnicze grupy osób, zajmujących się identyfikowaniem i ustalaniem wskaźników do oceny działalności przedsiębiorstwa, mających całkowicie odmienne priorytety, tj. na badaczy i przedsiębiorców. Priorytetem tych pierwszych jest klasyfikowanie i walidacja wskaźników oraz generalizowanie wniosków, a tych drugich - jak najszybsze uzyskanie informacji na podstawie wskaźników (czasami nawet kosztem jakości tych informacji).

Celem artykułu jest przybliżenie terminologii i metod oceny procesów zarządzania bhp oraz zaprezentowanie metody oceny skuteczności tych procesów jako wyniku rozważań teore tycznych i doświadczeń praktycznych przed siębiorstw, która mogłaby stanowić swoiste aureum medium.

\section{Skuteczność i efektywność procesów zarządzania bhp}

W literaturze przedmiotu i w praktyce przedsiębiorstw można spotkać wiele pojęć odnoszą cych się do oceny funkcjonowania organizacji jako całości oraz poszczególnych procesów organizacyjnych. Wśród najczęściej spotykanych można wymienić: skuteczność, efektywność sprawność i produktywność. Pojęcia te nie są ostre: często ten sam termin jest rozumiany inaczej przez różnych autorów, a innym razem różne terminy są ze sobą utożsamiane [7-9] Do tego chaosu terminologicznego z pewno ścią przyczynia się wielość pojęć stosowanych w literaturze anglojęzycznej, takich jak: effectiveness, efficiency, efficacy, performance, pro ductivity i ich różne przekłady na język polski $[8,9]$. Badacze podejmują prace mające na celu uporządkowanie terminologii w tym zakresie [7-9]. Zachodzi też konieczność doprecyzowa nia ich znaczenia w odniesieniu do procesów zarządzania bhp.

W prakseologii podstawowymi postaciami (walorami) sprawnego działania, zapobiegaja cego zjawisku chaotyczności i nieuporządkowania, którego miara jest entropia, są: skuteczność, korzystność i ekonomiczność. Inne postacie sprawności (czystość, dokładność, niezawodność) maja znaczenie dodatkowe [10]. Z prakseologicznego punktu widzenia sprawność jest więc pojęciem nadrzędnym, a do jego głównych miar należy zaliczyć skuteczność, korzystność i ekonomiczność.

Termin skuteczność oznacza zdolność do osiągnięcia ustalonego celu. Według Kieżuna skuteczność podlega stopniowaniu. Można za tem mówić o: pełnej skuteczności działań (gdy cel został zrealizowany w całości), częściowej skuteczności, działaniach nieskutecznych i dzia łaniach przeciwskutecznych (w sytuacji, gdy ich realizacja oddala od realizacji zaplanowanego celu) [10]

Korzystność, w literaturze przedmiotu często utożsamiana z wartością dodaną, stanowi różnicę między wynikiem a kosztami działania (zatem działanie jest korzystne, gdy ta różnica przyjmuje wartość większą od "0", przy poziomie "0" jest obojętne z punktu widzenia korzystności i wreszcie poniżej poziomu ${ }_{\text {}} 0$ " jest niekorzystne), a ekonomicznośćjest definiowana jako stosunek wyniku do kosztów działania (zatem działanie jest ekonomiczne, jeżeli stosunek ten przyjmuje wartość większą od „1", przy poziomie „1" jest obojętne z punktu widzenia ekonomiczności i wreszcie poniżej poziomu "0" jest niekorzystne). Skuteczne działania mogą być niekorzystne z ekonomicznego punktu widzenia [10, s. 18]

Tymczasem według Skrzypek pojęcie efektywności ma znaczenie nadrzędne nad pozostałymi i obejmuje swoim zakresem: skuteczność, sprawność, wydajność i produktywność [11]. Natomiast Gasparski utożsamia efektywność ze sprawnością i stawia je jako nadrzędne w stosunku do takich pojęć, jak: skuteczność i ekonomiczność [12]. Podgórski i Skład utożsamiają efektywność, a dokładnie efektywność operacyjną, z właściwie realizowanymi działaniami prowadzącymi do osiągnięcia założonego celu [13]. W literaturze przedmiotu termin efektywność niekiedy jest rozumiany jako właściwy sposób alokacji zasobów, jednak najczęściej jest utożsamiany z terminem ekonomiczność z prakseologicznego punktu widzenia i oznacza relację wyników do nakładów [7].

W obszarze zarządzania bhp można przyjąć, że w aspekcie oceny sprawnego działania tych procesów najistotniejsza jest ich skuteczność (czyli zdolność do osiągania celów, którymi są poprawa warunków pracy i ochrona zdrowia pracowników), a w mniejszym stopniu korzystność (którą można utożsamić z efektywnością). Ta ostatnia z oczywistych powodów ma znaczenie drugorzędne, a nie wszystkie działania w obszarze bhp, które można określić jako skuteczne, można też uznać za efektywne, zwłaszcza gdy tego typu analizy dotyczą krótkiego okresu. Zwrot z inwestycji w bezpieczeństwo i higienę pracy często widać dopiero w dłuższym czasie, a do oceny efektywności tych działań najczęściej stosuje się analizy. Do oceny efektywności w tym obszarze najlepiej stosować analizy kosztów i korzyści, czyli - z prakseologicznego punktu widzenia - z zastosowaniem miary korzystności $[14,15]$

\section{Wiodące i wynikowe wskaźniki procesów zarządzania bhp}

Skuteczność procesów bhp może być mierzona dwojako: a posteriori i a priori [16-19]. Ocena a posteriori oznacza nic innego jak ocenę skutków tychże procesów, co najczęściej sprowadza się do wyznaczenia poziomu wypadków przy pracy i chorób zawodowych, rzadziej chorób związanych z pracą, oraz absencji chorobowej jako takiej. Najczęściej używa się tu wskaźników częstości, wyrażonych stosunkiem liczby wypadków przy pracy, chorób zawodowych czy dni absencji chorobowej do ogólnej liczby zatrudnionych. Rzadziej przedsiębiorstwa stosują wskaźnik ciężkości wypadków przy pracy, mierzony stosunkiem liczby wypadków

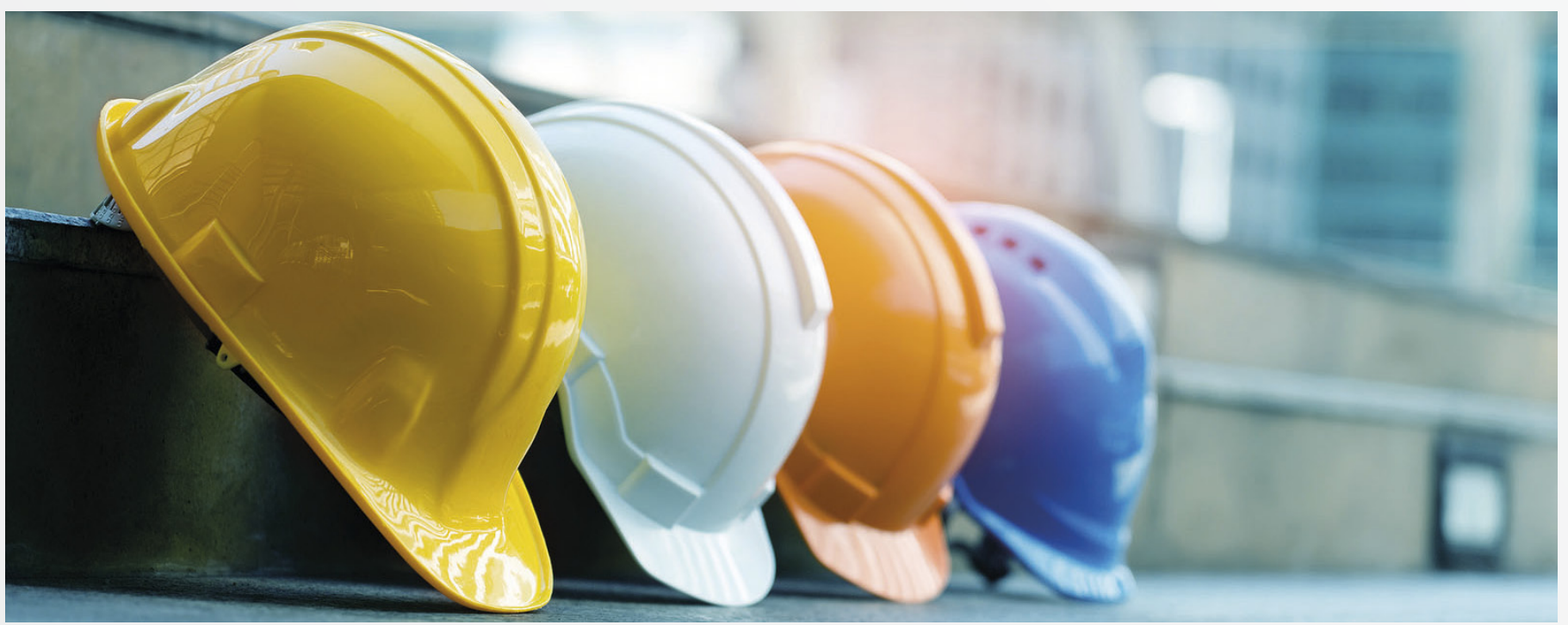




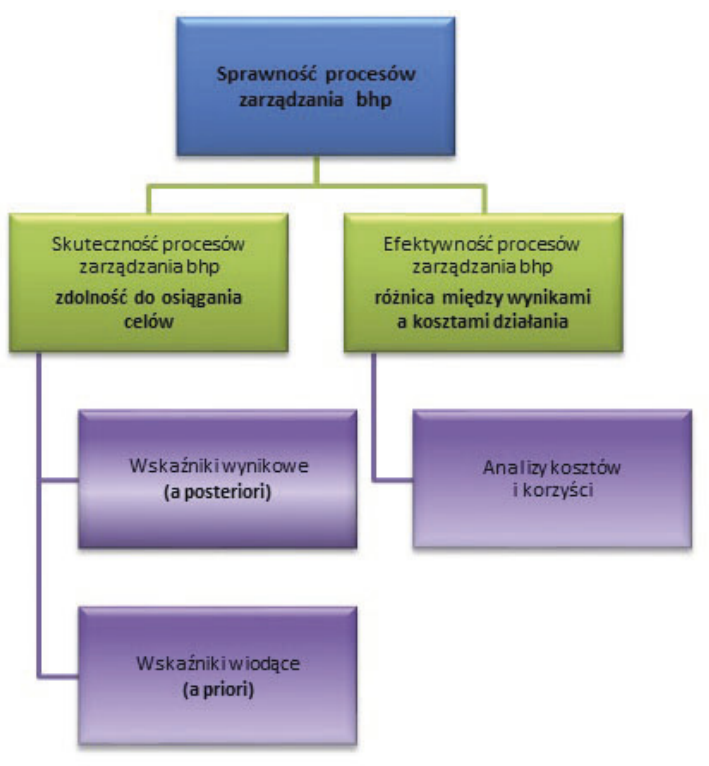

Rys. 1. Miary oceny realizacji procesów zarządzania bhp (źródło: opracowanie własne)

Fig. 1. Measurements of the performance of OSH management processes (source: own study)

przy pracy do liczby dni absencji wypadkowej. Wskaźniki wynikowe są na ogół łatwe do zastosowania z uwagi na to, że potrzebne dane są w każdym przedsiębiorstwie dostępne w zasadzie $w$ dowolnym czasie, a ponadto na ogół są znormalizowane i mogą być wprost stosowane do celów benchmarkingu' firm. Nie oznacza to jednak, że wymienione wskaźniki są całkowicie obiektywne, ponieważ liczba zatrudnionych pracowników nie jest równoznaczna z liczbą etatów czy rzeczywistym czasem pracy, a właśnie czas pracy, czyli ekspozycja na czynniki ryzyka, przekłada się na liczbę wypadków czy chorób zawodowych. Rzeczywisty czas pracy może być różny w różnych przedsiębiorstwach i w danym przedsiębiorstwie w zależności od okresu oceny, co wynika m.in. z przestojów, awarii lub względów ekonomicznych. Dlatego też wydaje się, że lepszymi miernikami skuteczności byłyby wskaźniki wypadków przy pracy w przeliczeniu na liczbę przepracowanych godzin czy dniówek. Poza wymienionymi metodami określania częstości wypadków w literaturze przedmiotu można spotkać propozycje obliczania tego wskaźnika np. W stosunku do wielkości produkcji w danym przedsiębiorstwie [20].

Trzeba pamiętać, że wszystkie te wskaźniki pozwalają mierzyć skuteczność procesów zarządzania bhp dopiero po wystąpieniu wypadku przy pracy czy choroby zawodowej, więc wskazują jedynie na istnienie problemu. Nie przydają się natomiast do bieżącego monitorowania procesów, nie pozwalają na zidentyfikowanie dysfunkcji i niezgodności występujących w organizacji ani na określenie możliwości usprawnień w celu uniknięcia niepożądanych zdarzeń.

Benchmarking - analiza porównawcza.
Ocena a priori, z zastosowaniem tzw. wskaźników wiodących, umożliwia monitorowanie prawidłowej realizacji procesów zarządzania bhp oraz identyfikację i ocenę występujących problemów, zanim zdarzy się wypadek czy pojawi się choroba zawodowa. Te wskaźniki pomagają niejako uprzedzić bieg zdarzeń oraz zaplanować i wdrożyć właściwe działania korygujące i zapobiegawcze. Poziom wartości wskaźników wiodą- • cych przekłada się więc na poziom wskaźników wynikowych. Wskaźniki te jednak nie opierają • się na obiektywnych danych liczbowych i dla- • tego ich oszacowanie jest stosunkowo trudne - • przeważnie określa się je na podstawie informacji zebranych w trakcie audytów, badań . ankietowych i obserwacji bądź danych liczbo- . wych, których zgromadzenie bywa czasochłonne • i kosztowne. Przykładem wskaźnika mierzonego • za pomocą kwestionariuszy może być poziom . kultury bezpieczeństwa (wskaźnik wyznaczany • na bazie szacunkowych danych dostarczanych przez specjalistów ds. bhp) lub nadzór (szacun- • kowy odsetek pracowników stosujących zasadę • 5S), a przykładem wskaźnika opartego na danych • liczbowych - wskaźnik zachowań niebezpiecz- • nych (mierzony zarejestrowaną liczbą takich zachowań w przeliczeniu na jednego pracownika). Warto też zwrócić uwagę na wskaźniki, które można traktować jako wynikowe, ponieważ wskazują na zaistniały skutek złego zarządzania bhp, ale w stosunku do innych wskaźników wynikowych mogą być traktowane jako wiodące - np. wskaźniki zdarzeń potencjalnie wypadkowych w stosunku do wskaźników wypadków przy pracy oraz wyniki pomiarów czynników niebez piecznych w stosunku do wskaźników chorób zawodowych (rys. 1.)

\section{Metoda oceny skuteczności procesów zarządzania bhp}

Dobór wskaźników do oceny skuteczności systemów zarządzania bhp zależy m.in. od jej celu. Specyfika każdego przedsiębiorstwa powoduje, że praktycznie każde z nich stosuje swój zindywidualizowany zestaw wskaźników, który pozwala się skoncentrować na aspektach najważniejszych z punktu widzenia zarządzania bhp. Takie podejście jest jak najbardziej uzasadnione, jednak nie daje możliwości porównywania się z innymi przedsiębiorstwami.

W dalszej części dokonano porównania dwóch odmiennych narzędzi komputerowych do oceny procesów zarządzania bhp. Pierwsze jest narzędziem zindywidualizowanym, a drugie może służyć nie tylko do oceny wewnątrzorganizacyjnej, lecz także do benchmarkingu firm. Do opracowania obu narzędzi wykorzystano ekspercką wiedzę pracowników naukowych CIOP-PIB oraz praktyczne doświadczenie specjalistów ds. bhp i kadry zarządzającej.

Pierwsze narzędzie KPI-OSH Tool jest oparte na 27 kluczowych wskaźnikach efektywności operacyjnej (key performance indicators, KPIs) [21], czyli wskaźnikach wiodących przyporządkowanych do odpowiednich elementów systemu zarządzania bhp według modelu przyjętego w projekcie normy ISO 45001 [22], obejmujących zwłaszcza:

- przywództwo i zaangażowanie

organizacyjne role, obowiązki, obszary odpowiedzialności i uprawnienia

identyfikację zagrożeń

ocenę ryzyka bhp

planowanie działań

planowanie realizacji celów bhp

kompetencje - skuteczność szkoleń

kompetencje - monitorowanie kompetencji pracowników

świadomość

informację i komunikację

partycypację, konsultacje i szkolenie

operacyjne planowanie i kontrolę

zakupy

podwykonawców

gotowość i reagowanie na awarie

monitorowanie, pomiary, analizy i ocenę

proces audytu wewnętrznego

przegląd zarządzania

zdarzenia wypadkowe, niezgodności i działania korygujące

- ciągłe doskonalenie.

W narzędziu KPI-OSH zastosowano wskaźniki ilościowe oparte na danych liczbowych, które trzeba pozyskać wewnątrz organizacji. Każdemu ze wskaźników przypisano poziomy referencyjne, które niejako podpowiadają użytkownikom, czy dany proces jest realizowany prawidłowo, czy też trzeba podjąć działania naprawcze. Narzędzie to pozwala dostosować zestaw wskaźników do indywidualnych potrzeb danego przedsiębiorstwa, nie tylko poprzez wybór 


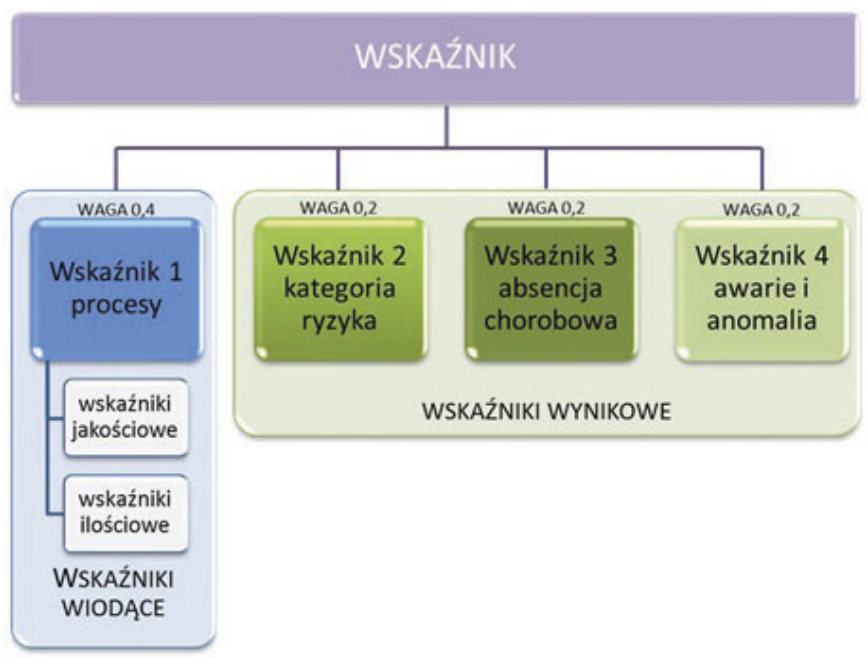

Rys. 2. Zintegrowany Wskaźnik Procesów BHP (ZWP-BHP) (źródło: opracowanie własne) Fig. 2. Integrated Indicator of OSH Processes (ZWP-BHP) (source: own study)

poszczególnych wskaźników z proponowanego zestawu, lecz także poprzez zdefiniowanie własnych wskaźników. Oceny skuteczności procesów zarządzania bhp dokonuje się tylko na poziomie pojedynczych wskaźników [13, 23].

Opracowywany obecnie w CIOP-PIB Zintegrowany Wskaźnik Procesów BHP (ZWP-BHP2) bazuje na innym podejściu, stosowanym już wcześniej zarówno przez zagranicznych ekspertów [24, 25], jak i ekspertów z CIOP-PIB autorów Zintegrowanego Wskaźnika Zarządzania BHP [26] (obecnie już nieaktualnego z uwagi na opracowanie nowej normy dotyczącej systemów zarządzania bhp [22]). Proponowana metoda zakłada ocenę dziewięciu procesów zarządzania bhp za pomocą wskaźników wiodących jakościowych, opartych na listach kontrolnych, i ilościowych, przyjmujących za podstawę szacunkowe dane dostarczane przez ekspertów z wewnątrz przedsiębiorstwa. ZWP-BHP obejmuje takie procesy, jak:

- komunikowanie się wewnątrz organizacji oraz konsultowanie

- identyfikacja potrzeb szkoleniowych oraz zapewnienie wiedzy i świadomości

- identyfikacja ryzyk i szans dla systemu zarządzania bhp

- identyfikacja ryzyk i szans dla bezpieczeństwa izdrowia

- reagowanie na dysfunkcje

- monitorowanie aktywne aspektów bhp

- monitorowanie reaktywne aspektów bhp

- monitorowanie zdrowia pracowników

- przegląd dokonywany przez najwyższe kierownictwo.

To narzędzie pozwala na ocenę poszczególnych procesów osobno oraz na wyznaczenie dla nich jednego uśrednionego wskaźnika.

2 Omawiane narzędzie pn. Zintegrowany Wskaźnik Procesów BHP (ZWP-BHP) zostało opracowane w formie aplikacji i jest obecnie $w$ fazie testowania.
W tym narzędziu zastosowano ponadto trzy wskaźniki wynikowe:

- wskaźnik odnoszący się do kategorii ryzyka przedsiębiorstwa, wyliczany zgodnie z ustawą o ubezpieczeniu z tytułu wypadków przy pracy i chorób zawodowych [27] - wskaźnik uwzględnia więc nie tylko wielkość przedsiębiorstwa, liczbę wypadków przy pracy i osób zatrudnionych w warunkach zagrożenia, lecz także poziom bezpieczeństwa dla branży, w której działa przedsiębiorstwo

- wskaźnik absencji chorobowej

- wskaźnik awarii i anomalii, oparty na liczbie niepożądanych zdarzeń w przedsiębiorstwie. Prezentowane podejście zakłada możliwość oceny działań przedsiębiorstwa zarówno na poziomie procesów organizacyjnych w zakresie bhp, jak i na poziomie poszczególnych podwskaźników odnoszących się do tych procesów (co moż- na wykorzystać do ich diagnozy), a ponadto pozwala na ocenę działań za pomocą wskaźników wynikowych oraz jednego ogólnego wskaźnika zintegrowanego (co można wykorzystać do monitorowania zmian w zakresie skuteczności zarządzania bhp oraz do porównywania międzyorganizacyjnego). Omawiane możliwości narzędzia ZWP-BHP przedstawiono na rys. 2.

W tabeli porównano omawiane narzędzia do oceny skuteczności procesów zarządzania bhp, przy czym należy zaznaczyć, że to porównanie w żaden sposób nie wskazuje, który z programów jest lepszy do wdrożenia w konkretnym przedsiębiorstwie.

\section{Podsumowanie}

Analiza literatury i doświadczeń ze współpracy z przedsiębiorstwami pokazuje, że istnieje potrzeba prowadzenia oceny skuteczności działań skierowanych na poprawę bezpieczeństwa i higieny pracy. Jednakże tego zadania nie ułatwia przedsiębiorstwom swoisty chaos, który wynika z braku reżimu terminologicznego w zakresie oceny procesów zarządzania bhp i z niemal nieograniczonej liczby wskaźników możliwych do zastosowania, dostępnych w literaturze przedmiotu i internecie. Potrzebne są więc gotowe, kompleksowe narzędzia do oceny skuteczności procesów zarządzania bhp, choć należy pamiętać, że nie ma jednego optymalnego programu czy jednej optymalnej metody oceny. Warto też mieć na uwadze, że de facto nie istnieją obiektywne wskaźniki, a poziomy referencyjne są tylko umowne. Ich interpretacja powinna zatem obejmować analizę porównawczą, uwzględniającą różne punkty w czasie i - jeśli to możliwe - inne jednostki organizacyjne, a ponadto powinna zostać skonfrontowana z wiedzą ekspercką specjalistów ds. bhp i nadzoru oraz potwierdzona obserwacjami pracowników i wywiadami z nimi.

Tabela. Porównanie wybranych cech programów do oceny skuteczności procesów zarządzania bhp

Table. Comparison of selected features of programs for assessing the effectiveness of OSH management processes

\begin{tabular}{|l|c|c|}
\hline \multicolumn{1}{|c|}{ Cecha } & KPI-OSH Tool & ZWP-BHP \\
\hline Wskaźniki wynikowe & nie \\
\hline Wskaźniki wiodące & tak tak \\
\hline Wskaźniki ilościowe & tak tak \\
\hline Wskaźniki jakościowe & nie & tak \\
\hline Możliwość indywidualizacji wskaźników & tak nie \\
\hline Diagnozowanie niesprawności & tak & tak \\
\hline Monitorowanie zmian & tak tak \\
\hline Ocena na poziomie zintegrowanym & nie & tak \\
\hline Porównywanie wewnątrzorganizacyjne & tak & tak \\
\hline Benchmarking międzyorganizacyjny & nie & tak \\
\hline Wartości referencyjne & tak & nie \\
\hline
\end{tabular}




\section{BIBLIOGRAFIA}

[1] URBAN, W. Pomiar procesów organizacyjnych w usługach - studia przypadków. Zarządzanie i Finanse. 2012, 3: 446-459.

[2] BITKOWSKA, A., PIAৃTKOWSKI, Z., ŻEBROWSKI, W. Controlling procesów biznesowych. Postępy Techniki Przetwórstwa Spożywczego. 2008, 1: 103-106.

[3] MELNYK, S.A., STEWART, D.M., SWINK, M. Metrics and performance measurement in operations management: dealing with the metrics maze. Journal of Operations Management. 2004 22: 209-217.

[4] KASUL, R.A., MOTWANI, J.G. Performance measurement in world-class operations: a strategic method. Benchmarking for Quality Management and Technology. 1995, 2: 20-36.

[5] ITTNER, C.D., LARCER, D.F. Coming short on nonfinancial performance measurement. Harvard Business Review. 2003, 11: 88-95.

[6] PETERSEN, D. Safety management 2000: our strengths and weaknesses. Professional Safety 2000, 1: 6-19.

[7] KOZUŃ-CIEŚLAK, G. Efektywność-rozważania nad istotą i typologią. Kwartalnik Kolegium Eko nomiczno-Społecznego Studia i Prace/Szkoła Główna Handlowa. 2013, 4: 13-42.

[8] PYSZKA, A. Istota efektywności. Definicje i wymiary. Studia Ekonomiczne. Zeszyty Naukowe Uniwersytetu Ekonomicznego w Katowicach 2015, 230: 13-25.

[9] KOWAL, W. Skuteczność i efektywność zróżnicowane aspekty interpretacji. Organizacja i Kierowanie. 2013, 157(4): 11-23.

[10] KIEŻUN, W. Sprawne zarządzanie organizacją. Warszawa: Oficyna Wydawnicza SGH, s. 18

[11] SKRZYPEK, E. Jakość i efektywność. Lublin: Wydawnictwo UMCS, 2000

[12] GASPARSKI, W. Decyzje i etyka. Normy uczciwości. Decydent \& Decision Maker. 2008, 74.

[13] PODGÓRSKI, D., SKŁAD, A. Komputerowe narzędzie do pomiaru efektywności operacyjnej systemów zarządzania bezpieczeństwem i higieną pracy z wykorzystaniem Kluczowych Wskaźników Efektywności. Problemy Jakości. 2016, 4: 2-8.

[14] RZEPECKI, J. Koszty i korzyści wdrażania systemów zarządzania bezpieczeństwem i higieną pracy w przedsiębiorstwach. Bezpieczeństwo Pracy. Nauka i Praktyka. 2006, 12, 423: 8-12.

WWW.CIOP.PL

\section{e-mail: \\ bpredakcja@ciop.pl}

[15] International Social Security Association (ISSA). The return on prevention: Calculating the costs and benefits of investment in occupational safety and health in companies. Summary of results. Research Report. Geneva 2011.

[16] LINGARD, H., et al. Leading or lagging? Temporal analysis of safety indicators on a large infrastructure construction project. Safety Science. 2017, 91: 206-220.
[17] REIMAN, T., PIETIKÄINEN, E. Leading indicators of system safety - Monitoring and driving the organizational safety potential. Safety Science. 2012, 50: 1993-2000.

[18] SINELNIKOV, S., INOUYE, J., KERPER, S. Using leading indicators to measure occupational health and safety performance. Safety Science. 2015 , 72: $240-248$.

[19] SWUSTE, P., et al. Journal of Loss Prevention in the Process Industries. 2016, 40: 162-173.

[20] RZEPECKI, J. Przydatność wskaźników wypadkowości do oceny ryzyka zawodowego. Bezpieczeństwo Pracy. Nauka i Praktyka. 1987, 194(9): 8-10.

[21] PĘCI ŁŁO, M., SKŁAD, A. Application of Process Approach to OSH Management. [In:] D. Podgórski (ed.), New Opportunities and Challenges in Occupational Safety and Health Management. CRC Press Taylor \& Francis Group, 2020, pp. 7-33. [22] PN-ISO 45001:2018-06 Systemy zarządzania bezpieczeństwem i higieną pracy - Wymagania i wytyczne stosowania.

[23] PODGÓRSKI, D. Measuring operational performance of OSH management system - A demonstration of AHP-based selection of leading key performance indicators. Safety Science. 2015, 73: $146-166$

[24] MEARNS, K., et al. Benchmarking human organizational factors in offshore safety. [In:] Factoring the human into safety: Translating research into practice. Vol. 1. Research Report 059. London: Health and Safety Executive, 2003.

[25] SARACINO, A., et al. Quantitative assessment of occupational safety and health: Application of a general methodology to an Italian multi-utility company. Safety Science. 2015, 72: 75-82.

[26] PAWŁOWSKA, Z. Jak oceniać funkcjonowanie przedsiębiorstwa w obszarze bezpieczeństwa i higieny pracy? Bezpieczeństwo Pracy. Nauka i Praktyka. 2006, 413(2): 5-7.

[27] Ustawa z dnia 30 października 2002 r. o ubezpieczeniu społecznym z tytułu wypadków przy pracy i chorób zawodowych (t.j. Dz.U. z 2019 r. poz. 1205, z późn. zm.).

Opracowano $i$ wydano na podstawie wy ników V etapu programu wieloletniego "Poprawa bezpieczeństwa i warunków pracy", finansowanego w zakresie zadań służb pań stwowych ze środków Ministerstwa Rodziny Pracy i Polityki Społecznej (zadanie nr 2.SP.30 pt. „Wspomaganie oceny skuteczności proce sów zarządzania bezpieczeństwem i higiena pracy"). Koordynator programu: Centralny Instytut Ochrony Pracy - Państwowy Instytut Badawczy. 